\title{
AN EVALUATION OF THE RESIDUAL ACTIVITY OF TRADITIONAL, SAFE, AND BIOLOGICAL INSECTICIDES AGAINST THE GYPSY MOTH
}

\author{
by Ralph E. Webb1, Randy Peiffer ${ }^{2}$, Roger W. Fuester ${ }^{3}$, Kevin W. Thorpe', \\ Louis Calabrese ${ }^{2}$, and Joseph M. McLaughlin²
}

\begin{abstract}
We evaluated the direct and the residual efficacy of selected traditional, safer, and biological insecticides that are either registered or are candidates for registration for use by arborists and nurserymen in Integrated Pest Management (IPM) programs for gypsy moth (Lymantria dispar) management in urban settings. The study compared 5 biological insecticide treatments (1 Bacillus thuringiensis [Bf] and 4 gypsy moth nuclear polyhedrosis virus [NPV] treatments) and 2 reduced-risk insecticides (neem and tebufenozide) against 2 commonly used standard insecticides (diflubenzuron and cyfluthrin). Significant details pertaining to the use of the specific control materials were clarified in support of a decision matrix around which an IPM system can be formulated for use by arborists and nurserymen. The standard insecticides, cyfluthrin and diflubenzuron, and the ecdysone agonist tebufenozide, demonstrated excellent activity against all instars in both a 1hour residue study and a 35-day residue study. Bt was clearly more effective against second instar larvae than against fourth instar larvae and lost significant activity against the gypsy moth after 7 days. The efficacy of the neem product was similar to that of $B t$ in that it controlled younger instars better than it did older instars. Although its speed of action was slower than that of $B t$, it remained highly active against gypsy moth 21 days after treatment. NPV without the activity enhancer $\mathrm{Blankophor} \mathrm{BBH}$ gave significant levels of control for all 4 larval instars fed on 1-hour residues, although mortality was higher for younger instars than for older instars. Residual effectiveness was significantly reduced after 1 day. The addition of Blankophor BBH to the NPV tank mix led to improved kill in the 1-hour study and to vastly improved residual activity (up to 35 days).
\end{abstract}

Although a number of conventional insecticides are registered for and used against the gypsy moth (Lymantria dispar) by arborists and nurserymen, Bacillus thuringiensis $(B t)$ is the only biological/reduced-risk insecticide that is currently in wide use. Arborists and nurserymen face a variety of situations when dealing with the gypsy moth in nurseries and on shade trees in urban and suburban settings. Control materials might not be equally suitable for all situations or compatible with all treatment philosophies. In some cases (situation 1), shade trees will be sprayed while gypsy moth larvae are young (instars 1-2), with little possibility of reinfestation from neighboring untreated trees. In other cases (situation 2), shade trees will be sprayed while gypsy moth larvae are young, but there is a high probability of reinfestation from neighboring trees. However, at many sites, infestations are not noticed until larvae are in instars 3,4, or later (situation 3). Finally, nurserymen, in compliance with quarantine regulations, may or may not ship stock into gypsy-moth-free areas, which may influence the choice of control materials (situation 4). Situation 1 lends itself to a variety of control options. Situation 2 calls for a material with residual activity. Control options appropriate for situation 1 might be unacceptable for situation 3 , while situation 4 might require higher levels of control than is necessary for the other situations.

In a continuation of studies designed to improve ground-based control tactics against the gypsy moth (Webb et al. 1994a; Webb et al. 1994b; Thorpe et al. 1995; Thorpe 1996; Webb et al. 1996), we compared the residual activities of insecticides that are either registered or are candidates for registration for use by nurserymen or by arborists in Integrated Pest Management (IPM) programs for gypsy moth management in urban settings. The study compared 5 biological insecticide treatments ( $1 \mathrm{Bt}$ and 4 gypsy moth nuclear polyhedrosis virus [NPV] treatments) and 2 reduced-risk insecticides (neem and tebufenozide) against 2 commonly used standard insecticides (diflubenzuron and cyfluthrin). Significant details pertaining to the use of the specific control materials were clarified in support of a decision matrix around which an IPM system can be formulated for use by arborists and nurserymen. 


\section{Materials and Methods}

Eighty groups of 15 accessible oak branch tips (primarily pin oak [Quercus palustris]) were marked along the edge of a forest clearing in the Cedar Swamp Wildlife Area northeast of Smyrna, Delaware, in the spring of 1996 . There was no evident natural gypsy moth population in the woodlot. Each group of tips was separated by at least $10 \mathrm{~m}(33 \mathrm{ft})$. The groups of tips were divided into 8 blocks of 10 , and each block was randomly assigned 10 treatments, 1 per group of 15 tips, for a randomized block experimental design with 8 replications. All insecticides (Table 1) were applied in distilled water on May 13, 1996, following label directions and in consultation with manufacturer agents. Differences in dosage rates and the presence or absence of stickers reflect label or manufacturer requirements or suggestions. The first 4 treatments were combinations of Gypchek (gypsy moth nuclear polyhedrosis virus, LD226 strain, USDA Forest Service, Hamden, Connecticut) and Blankophor BBH (disodium salt of 2,2'-(1,2-ethenediyl) bis (5(4-(4morpholinyl)-6-(phenylamino)-1,3,5-triazin-2-yl) amino-benzenesulfonic acid [CAS No. 16090-021], Burlington Chemical, Burlington, North Carolina), and were 1) Gypchek at $1 \times 10^{11}$ occlusion bodies (OB) per $378 \mathrm{~L}$ (100 gal) final solution; 2 ) Gypchek at $1 \times 10^{12}$ OB per $378 \mathrm{~L}$ final solution; 3) Gypchek at $1 \times 10^{11} \mathrm{OB}$ plus $0.1 \%$ (wt:vol) Blankophor BBH per $378 \mathrm{~L}$ final solution; and 4) Gypchek at $1 \times 10^{11} \mathrm{OB}$ plus $0.5 \%$ (wt:vol)
Blankophor BBH per $378 \mathrm{~L}$ final solution. All 4 of the above treatments were applied with $2 \%$ (v/v) Bond sticker (Loveland Industries, Greeley, Colorado).

Treatment 5 consisted of Bt (Foray 48B, Abbott Laboratories, North Chicago, Illinois) at $2.84 \mathrm{~L}(0.7 \mathrm{gal}, 36 \mathrm{BIU})$ per $378 \mathrm{~L}$ final solution without sticker. Treatment 6 consisted of azadirachtin (an active compound from the neem plant) (Azatin 4.5 WP, biosys, Columbia, Maryland) at $267 \mathrm{~g}$ formulation per $378 \mathrm{~L}$ final solution (= $12 \mathrm{~g}$ a.i.) applied twice at 7 days apart, with $0.125 \%$ Dragon (Dragon Corp., Roanoke, Virginia) spreader-sticker (containing alkyl aryl polyoxyethelene glycols). Treatment 7 consisted of tebufenozide (as Experimental Insecticide RH-5992 2F, Rohm and Haas, Philadelphia, Pennsylvania) at $237 \mathrm{~mL}$ per $189 \mathrm{~L}$ final solution (label recommends 8 oz per $50 \mathrm{gal}$ solution per acre), with $0.25 \%(\mathrm{v} / \mathrm{v})$ Bond sticker. Treatment 8 consisted of diflubenzuron (as Dimilin 25 W, Uniroyal Chemical Co., Naugatuck, Connecticut) at $237 \mathrm{~mL}$ per $378 \mathrm{~L}$ final solution, without added sticker. Treatment 9 consisted of cyfluthrin (as Tempo 2, Bayer Corporation, Kansas City, Missouri) at $30 \mathrm{~mL}$ per $378 \mathrm{~L}$ final solution, with $0.25 \%(\mathrm{v} / \mathrm{v})$ Bond sticker. Treatment 10 consisted of unsprayed branch tips (experimental controls). Sprays were applied to runoff using a backpack sprayer at 20 psi.

Laboratory-reared gypsy moth larvae from a colony maintained at Beneficial Insects

Table 1. Treatments evaluated in this study.

\begin{tabular}{llll}
\hline \multicolumn{2}{l}{ Treatment and product } & Dose per 378 L & Adjuvants added \\
\hline 1. Gypchek & NPV (low) & $10^{11} \mathrm{PIB}$ & $2 \%$ (vol/vol) Bond sticker \\
2. Gypchek & NPV (standard) & $10^{12} \mathrm{PIB}$ & $2 \%$ (vol/vol) Bond sticker \\
3. Gypchek & NPV (low) & $10^{11} \mathrm{PIB}$ & $2 \%$ (vol/vol) Bond sticker \\
(enhanced) & $+0.1 \% \mathrm{BBH}$ & & \\
4. Gypchek & NPV (low) & $10^{11} \mathrm{PIB}$ & $2 \%(\mathrm{vol} / \mathrm{vol})$ Bond sticker \\
(enhanced) & $+0.5 \% \mathrm{BBH}$ & & \\
5. Foray 48B & Bacillus thuringiensis & No sticker at manufacturer's suggestion \\
& 36 Billion International Units (BIU) & $2.84 \mathrm{~L}$ formulated product \\
6. Azatin 4.5 WP & azadirachtin & $267 \mathrm{~g}$ & $0.125 \%$ (vol/vol) Dragon spreader-sticker \\
7. RH-5992 2F & tebufenozide & $474 \mathrm{~mL}$ & $0.25 \%$ (vol/vol) Bond sticker \\
8. Dimilin 4L & diflubenzuron & $59 \mathrm{~mL}$ & No sticker at manufacturer's suggestion \\
9. Tempo 2 & cyfluthrin & $30 \mathrm{~mL}$ & $0.25 \%$ (vol/vol) Bond sticker \\
10. Untreated controls & &
\end{tabular}

Blankophor BBH (BBH) is a stilbene disulfonic acid derivative used as by industry as an optical brightener but was here used as a potentiator of the gypsy moth nuclear polyhedrosis virus (NPV). NPV virions (individual virus particles) are contained in protective protein polygons (containing a variable number of virions) called polyhedral inclusion bodies (PIB).

Introduction

Research, Newark, Delaware, were placed in bags fastened over $t r$ e a t e d branch tips and then tied off. Four tips from each of the 80 groups of branch tips were bagged for a 1-hour evaluation, 
with a bag from each group receiving 10 firstinstar, a second bag receiving 10 second-instar, a third bag receiving 10 third-instar, and the fourth bag receiving 10 fourth-instar larvae. Subsequent bags were placed over a tip from each of the 80 groups of tips $1,2,7,14,21,28$, and 35 days after treatment, with 10 larvae (second-instar, days $1,2,7$; third-instar, days 14,21 ; fourth-instar, days 28,35$)$ added per bag. Bags consisted of $60 \times 60 \mathrm{~cm}(23.6 \times 23.6 \mathrm{in}$.) squares of organza cloth seamed to make a bag. Larvae were left in the bags for 7 days and then were removed and placed, 1 per cup, in 30-cc plastic diet cups half filled with gypsy moth diet (Webb et al. 1993; Webb et al. 1994a; Webb et al. 1994c; Webb et al. 1996) and held under natural conditions in a field insectary (Webb et al. 1993; Webb et al. 1994a; Webb et al. 1994c; Webb et al. 1996). Mortality was assessed after 7, 15, and 21 days.

For the 1-hour study with 4 instars, data were analyzed by analysis of variance (ANOVA) using the General Linear Models (GLM) procedure of the SAS statistics package (SAS 1996). The data were analyzed as a randomized block design, with treatment by block interaction as the error term to test the significance of the treatment effect, while instar by block interaction was the error term to test the significance of the instar effect, and treatment by block by instar interaction was used as the error term for the treatment by instar effect. For the 1- to 35-day residue study, a repeated measures ANOVA was conducted by fitting a mixed linear model (Proc Mixed) to the data (SAS 1996). An unstructured covariance matrix was specified. Where the treatment effect was significant, means were separated at a comparison-wise error rate of 0.05 using the least significant difference (LSD) procedure (SAS 1996).

\section{Results}

Highly significant treatment effects were seen for insecticides for both the insecticide versus larval instar $(F=44.78 ; d f=9 ; P<0.01$ and the insecticide versus residual date portions of the study $(F=33.41 ; d f=9 ; P<0.01)$. As expected, there were highly significant instar effects $(F=20.76$; $d f=33 ; P<0.01$ ) (generally, younger larvae were more easily controlled than older larvae) and residual date effects $(F=11.66 ; d f=6 ; P<0.01)$ (generally, insecticide effectiveness eroded over time). More interestingly, treatment $x$ instar effects (some insecticides were controlling older larvae better than other insecticides) and treatment $x$ date effects (some insecticides were retaining residual effectiveness better than other insecticides) were highly significant $(F=1.96$; df $=27 ; P<0.01$; and $F=2.90 ; d f=54 ; P<0.01$ ). The specific treatment effectiveness by instar of larvae fed on 1-hour residues is given in Table 2. Gypsy moth larval mortality was significantly higher for all treatments against all larval instars when compared with untreated controls. All treatments except for the unenhanced NPV treatments ( 1 and 2 ) gave a level of control that was statistically equivalent to that of the standard insecticides (diflubenzuron and cyfluthrin, treatments 8 and 9) for instars 1 and 2. NPV enhanced by $0.5 \%$ Blankophor $\mathrm{BBH}, B t$, and tebufenozide gave a level of control that was statistically equivalent to that of the standard insecticides for third instar larvae, but only tebufenozide gave equivalent control for fourth instar larvae. Speed of kill by the various treatments of second and fourth instar larvae is given in Figure 1. Cyfluthrin gave complete control of both instars within 1 week, while tebufenozide and diflubenzuron both took 2 weeks to achieve such control. Bt took 2 weeks to achieve excellent control of second instars and partial control of fourth instar larvae, while the remaining treatments took 3 weeks to reach such control levels.

The residual effectiveness of the treatments ("active" defined as significantly different from untreated controls, "highly active" as not significantly different from standard insecticides) is given in Table 3 . Cyfluthrin, tebufenozide, and diflubenzuron all showed highly active residual activity for the 35 days of the study, while azadirachtin residues were highly active after 21 days and $B t$ residues highly active after 7 days. Unenhanced NPV was largely inactive 1 day after treatment, but active to highly active NPV activity was seen even after 35 days when enhanced with Blankophor $\mathrm{BBH}$, especially at the $0.5 \%$ concentration. The source of the control mortality was not determined. Three weeks in a cloth 
Table 2. Mortality of gypsy moth larvae of the indicated instars confined for 3 weeks on foliage bearing 1-hour residues of the indicated treatments.

\begin{tabular}{|c|c|c|c|c|c|c|}
\hline \multirow{2}{*}{\multicolumn{2}{|c|}{ Treatment and product }} & \multirow{3}{*}{$\frac{\text { Dose per } 378 \mathrm{~L}}{10^{11} \mathrm{PIB}}$} & \multicolumn{4}{|c|}{ Gypsy moth instar } \\
\hline & & & \multirow{2}{*}{$\frac{1}{91^{t t}}$} & \multirow{2}{*}{$\frac{2}{81^{\dagger}}$} & \multirow{2}{*}{$\frac{3}{61^{\dagger}}$} & \multirow{2}{*}{$\frac{4}{56^{\dagger}}$} \\
\hline 1. Gypchek & NPV (low) & & & & & \\
\hline 2. Gypchek & NPV (standard) & $10^{12} \mathrm{PIB}$ & $85^{\dagger}$ & $81^{\dagger}$ & $78^{\dagger}$ & $61^{\dagger}$ \\
\hline \multirow[t]{2}{*}{ Gypchek } & NPV (low) & $10^{11} \mathrm{PIB}$ & & & & \\
\hline & $+0.1 \% \mathrm{BBH}$ & & $97^{t \dagger}$ & $95^{t t}$ & $80^{\dagger}$ & $61^{\dagger}$ \\
\hline \multirow{2}{*}{$\begin{array}{l}\text { 4. Gypchek } \\
\text { (enhanced) }\end{array}$} & NPV (low) & $10^{11} \mathrm{PIB}$ & & & & \\
\hline & $+0.5 \% \mathrm{BBH}$ & & $98^{t t}$ & $97^{t \dagger}$ & $91^{t t}$ & $69^{\dagger}$ \\
\hline 5. Foray $48 \mathrm{~B}$ & $B t(36 \mathrm{BIU})$ & $2.84 \mathrm{~L}$ & $98^{t \dagger}$ & $97^{\dagger \dagger}$ & $86^{t+}$ & $78^{\dagger}$ \\
\hline 6. Azatin 4.5 WP & azadirachtin & $267 \mathrm{~g}$ & $97^{\dagger t}$ & $93^{t t}$ & $81^{\dagger}$ & $69^{\dagger}$ \\
\hline 7. $\mathrm{RH}-59922 \mathrm{~F}$ & tebufenozide & $474 \mathrm{~mL}$ & $100^{\dagger t}$ & $100^{t t}$ & $100^{t t}$ & $100^{\dagger \dagger}$ \\
\hline 8. Dimilin 4L & diflubenzuron & $59 \mathrm{~mL}$ & $100^{\dagger t}$ & $100^{t t}$ & $100^{t t}$ & $99^{\dagger+}$ \\
\hline 9. Tempo 2 & cyfluthrin & $30 \mathrm{~mL}$ & $100^{t t}$ & $100^{t+}$ & $100^{t t}$ & $100^{\dagger}$ \\
\hline \multicolumn{3}{|c|}{ 10. Untreated controls } & 41 & 32 & 40 & 24 \\
\hline
\end{tabular}

Values followed by at least 1 cross $(t)$ differ significantly from that of the experimental controls at the 0.05 probability level (LSD). Values followed by a double cross ( $\dagger \dagger$ ) are not significantly different from the standard traditional insecticide (Tempo 2) at the 0.05 probability level (LSD). cage will result in a certain amount of death through trauma, predation by spiders, etc.

\section{Discussion}

The results permit the arborist to develop a decision matrix to address the varied concerns of customers that include speed of kill, residual activity, and to a public increasingly concerned about the environment, the species-

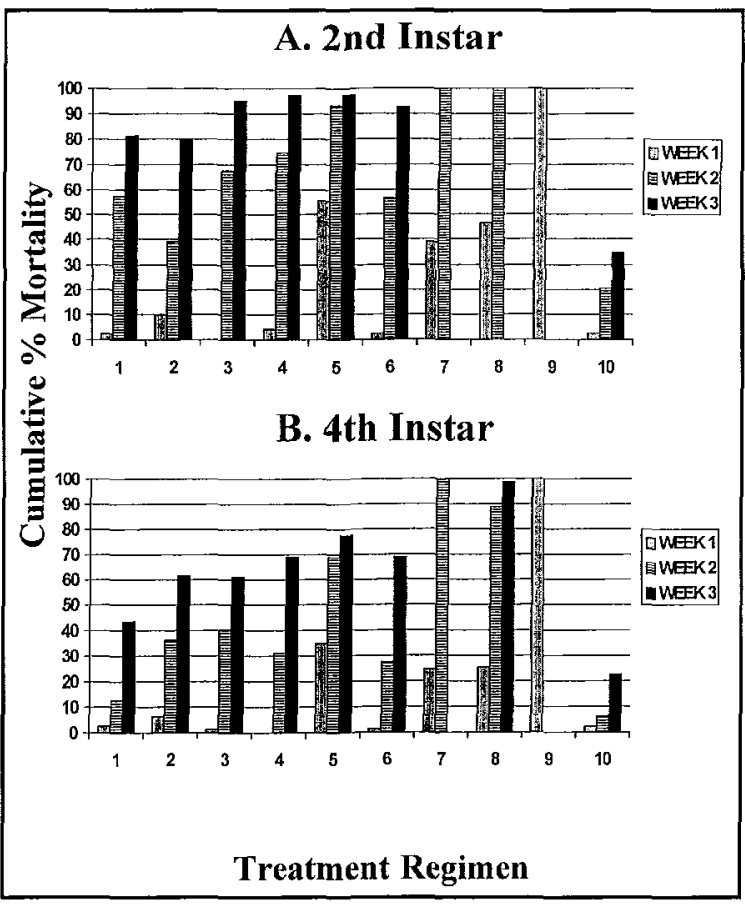

Figure 1. Mortality of (A) second instar and (B) fourth instar gypsy moths confined for 1, 2, and 3 weeks on foliage bearing 1 -hour residues of the indicated treatments: (1) NPV low dose, (2) NPV high dose, (3) NPV low dose $+0.1 \%$ Blankophor BBH, (4) NPV low dose $+0.5 \%$ Blankophor BBH, (5) $B t$, (6) azadirachtin, (7) tebufenozide, (8) diflubenzuron, (9) cyfluthrin, (10) untreated controls. specificity of control materials. As expected from previous studies (Webb et al. 1989; Webb et al. 1991; Thorpe et al. 1995), both of the standard insecticides, cyfluthrin and diflubenzuron, demonstrated excellent activity against all instars in the 1-hour residue study and for the 35 days of the extended residue study. Because cyfluthrin (a broad-spectrum synthetic pyrethroid) also gave a quick kill, which impresses customers and prevents additional foliar feeding, it would seem to be the material of choice. However, the use of broadspectrum insecticides can lead to outbreaks of secondary organisms (Raupp et al. 1992) such as scales, aphids, and mites. Ideally, an insecticide should be less active against the natural enemies of insect pests than it is against the pest itself (Bartlett 1963). The toxicity of cyfluthrin for secondary organisms compared to the predators and parasites of such organisms is unknown but is likely in some cases to be unfavorable. Diflubenzuron, an insect molting inhibitor, was nearly as efficacious as cyfluthrin against all 4 gypsy moth instars as a 1 -hour residue, and to provide an equivalent 35 day residual activity, and while slower acting, diflubenzuron is known to be relatively safe for adult predators and parasites (Wilkinson et al. 1978). Alone among the alternative insecticides tested, the ecdysone agonist tebufenozide gave high activity against all 4 larval instars and remained highly active for the 35 days of the residue study. Tebufenozide, known to be 
Table 3. Mortality of gypsy moth larvae confined on foliage bearing residues of the indicated ages for the indicated treatments.

\begin{tabular}{|c|c|c|c|c|c|c|c|c|}
\hline \multirow[b]{2}{*}{ Treatment } & \multirow[b]{2}{*}{ Dose per $378 \mathrm{~L}$} & \multicolumn{6}{|c|}{ Age of residue at time of confinement } & \multirow[b]{2}{*}{35} \\
\hline & & 1 & 2 & 7 & 14 & 21 & 28 & \\
\hline NPV & $10^{11} \mathrm{PIB}$ & 45 & 54 & 43 & 33 & $77^{\dagger}$ & 33 & 29 \\
\hline NPV & $10^{12} \mathrm{PIB}$ & $68^{\dagger}$ & 51 & 56 & 39 & 54 & 56 & 48 \\
\hline NPV & $10^{11} \mathrm{PIB}$ & & & & & & & \\
\hline$+\mathrm{BBH}$ & $0.1 \%$ & $78^{+\dagger}$ & $74^{\dagger}$ & $87^{+\dagger}$ & 43 & 47 & $73^{\dagger}$ & $69^{\dagger}$ \\
\hline NPV & $10^{11} \mathrm{PIB}$ & & & & & & & \\
\hline$+\mathrm{BBH}$ & $0.5 \%$ & $94^{+\dagger}$ & $87^{1 \dagger}$ & $79^{+\dagger}$ & $67^{t}$ & $68^{\dagger}$ & $83^{t+}$ & $80^{\dagger+}$ \\
\hline$B t(36 \mathrm{BIU})$ & $2.84 \mathrm{~L}$ & $94^{t+}$ & $93^{t+}$ & $79^{+t}$ & 42 & 38 & 57 & 48 \\
\hline Azadirachtin & $267 \mathrm{~g}$ & $84^{\dagger+}$ & $83^{t \dagger}$ & $100^{t t}$ & $81^{t t}$ & $95^{+\dagger}$ & 61 & 44 \\
\hline Tebufenozide & $474 \mathrm{~mL}$ & $100^{+\dagger}$ & $100^{t+}$ & $100^{t+}$ & $100^{+1}$ & $100^{t t}$ & $100^{\dagger t}$ & $100^{\dagger+}$ \\
\hline Diflubenzuron & $59 \mathrm{~mL}$ & $100^{\dagger+}$ & $100^{t+}$ & $100^{\dagger \dagger}$ & $69^{+}$ & $100^{\dagger t}$ & $100^{\dagger \dagger}$ & $100^{\dagger \dagger}$ \\
\hline Cyfluthrin & $30 \mathrm{~mL}$ & $100^{+t}$ & $100^{+t}$ & $100^{t \dagger}$ & $99^{t t}$ & $100^{t \dagger}$ & $100^{\dagger \dagger}$ & $100^{t+}$ \\
\hline \multicolumn{2}{|c|}{ Untreated controls } & 41 & 32 & 40 & 24 & 30 & 47 & 46 \\
\hline
\end{tabular}

Values followed by at least 1 cross ( $\dagger$ ) differ significantly from that of the experimental controls at the 0.05 probability level (LSD). Values followed by a double cross $(\dagger \dagger)$ are not significantly different from the standard traditional insecticide (Tempo 2) at the 0.05 probability level (LSD).

sparing of natural enemies (Brown 1996), and for that reason considered by the Environmental Protection Agency to be a "safer" insecticide, was equal to the standard insecticides in efficacy, although its speed of kill was similar to diflubenzuron.

Interest is increasing in the use of integrated pest management (IPM) in woody landscapes (Raupp et al. 1992) and in the evaluation of more natural control materials for use in these programs (Nielsen 1990). The natural insecticides evaluated here were $B t$, azadirachtin, NPV, and NPV with an enhancer. A properly timed application of $B t$, a bacterial insecticide, has been shown to provide satisfactory foliage protection from gypsy moth feeding, although levels of kill were less than that seen for cyfluthrin (Thorpe 1996). In the present study, Bt was clearly more toxic for second instar larvae than against fourth instar larvae, demonstrating the desirability of timing sprays against young larvae. The speed of kill for $B t$ was similar to that of diflubenzuron. Bt lost significant activity against the gypsy moth after 7 days. Extracts of seeds of the neem tree, Azadirachta indica, are known to be active against the gypsy moth (Skatulla and Meisner 1975). Although several compounds found in neem seed are insecticidal, the product used in this study, Azatin 4.5 WP, contains only 1 compound, azadirachtin. At the rate used in this study, azadirachtin efficacy against gypsy moth was similar to that of $B t$ in that it controlled younger for those who seek gypsy moth control with no impact on other "nontarget" organisms. Being a disease, it has the potential to do things that the standard insecticides cannot do, such as to grow, to persist, and to spread to nontreated areas. Thus treatment of the lower foliage of shade trees can immediately lead to significant levels of control in the treated area while leading to a lateseason epizootic that controls the gypsy moth population over the entire tree, and neighboring trees (Webb et al. 1990). Gypsy moth NPV, while registered with the EPA for use against gypsy moth, is not commercially available. However, our group and others are currently developing protocols for using NPV with ground equipment when it does become available (Webb et al. 1990; Podgwaite et al. 1991; Webb et al. 1993). USDAForest Service research has featured a tank mix of NPV plus a lignosulfonate sunscreen and a sticker (Webb et al. 1990); other work failed to confirm that a sunscreen helped the NPV when applied from the ground (Webb et al. 1993). However, NPV can be combined with other active compounds, such as neem (Shapiro et al. 1994; Cook et al. 1996), or with a stilbene disulfonic acid optical brightener such as Blankophor BBH (Webb et al. 1994a; Webb et al. 1994c; Webb et al. 1996). In laboratory bioassays, optical brighteners increase the potency of NPV by a thousand fold by a mechanism still under investigation, and also act as sunscreens (Dougherty et al. 
1996). Field studies have demonstrated that the addition of Blankophor BBH to NPV tank mixes results in increased speed of kill and percent of kill, especially against older larvae (Webb et al. 1994a; Webb et al. 1994c; Webb et al. 1996), and with the suggestion of increased residual effectiveness. In the present study, both doses of NPV without Blankophor BBH gave significantly increased (compared with controls) levels of mortality against all 4 larval instars fed on 1 -hour residues, although mortality of younger instars was higher than that of older instars. A tenfold increase in dose did not lead to an obvious increase in effectiveness, except that the higher dose did retain significant activity for 1 day following treatment, while the lower dose lacked such activity. The addition of Blankophor BBH led to improved kill in the 1-hour study and to improved residual activity, with the $0.5 \%$ rate giving substantially better control than the $0.1 \%$ rate. The activity seen against larvae fed on 35-day residues is consistent with our previous report of extended activity (Webb et al. 1996).

Acknowledgements. The authors thank Philip Taylor for rearing the larvae used in this study, and Brad Thomas, Karen Massey, Andrea Pipes, David Leitch, Heather Harder, Jay Davis, Leroy Dohman, Kara Fewlass, and Sydney Young for assistance with the field work.

\section{Literature Cited}

Bartlett, B.R. 1963. The contact toxicity of some pesticide residues to hymenopterous parasites and coccinellid predators. J. Econ. Entomol. 56: 694-698.

Brown, J.J. 1996. The compatibility of tebufenozide with a laboratory Lepidopteran host/ Hymenopteran parasitoid population. Biol. Control 6: 96-104.

Cook, S.P., R.E. Webb, and K.W. Thorpe. 1996. Potential enhancement of the gypsy moth (Lepidoptera: Lymantriidae) nuclear polyhedrosis virus with the triterpene azadirachtin. Environ. Entomol. 25: 1209-1214.

Dougherty, E.M., K.P. Guthrie, and M. Shapiro. 1996. Optical brighteners provide baculovirus activity enhancement and UV radiation protection. Biol. Control 7: 71-74.
Nielsen, D.G. 1990. Evaluation of biorational pesticides for use in arboriculture. J. Arboric. 16:82-88.

Podgwaite, J.D., R.C. Reardon, D. Kolodny-Hirsch, and G.S. Walton. 1991. Efficacy of ground application of gypsy moth (Lepidoptera: Lymantriidae) nucleopolyhedrosis virus product, Gypchek. J. Econ. Entomol. 84:440-444.

Raupp, M.J., C.S. Koehler, and J.A. Davidson. 1992. Advances in implementing pest management for woody landscape plants. Annu. Rev. Entomol. 37:561-585.

SAS Institute Inc. 1996. SAS/STAT Software: Changes and Enhancements through Release 6.11. Cary, NC.

Shapiro, M., J.L. Robertson, and R.E. Webb. 1994. Effect of neem extract upon the gypsy moth (Lepidoptera: Lymantriidae) and its nuclear polyhedrosis virus. J. Econ. Entomol. 87: 356-360.

Skatulla, U., and J. Meisner. 1975. Effects of neemextracts on caterpillars of the gypsy moth, Lymantria dispar L. Anz. Schadlingsk. Pflanzenschutz Umweltschutz 48:38-40.

Thorpe, K.W. 1996. Effects of ground-based applications of soap. Bacillus thuringiensis, cyfluthrin, and trunk barriers on gypsy moth density and defoliation. J. Arboric. 22:87-91.

Thorpe, K.W., K.M. Tatman, P. Sellers, R.E. Webb, and R.L. Ridgway. 1995. Management of gypsy moths using sticky barriers and larval removal. J. Arboric. 21:69-76.

Webb, R.E., M. Shapiro, J.D. Podgwaite, R.C. Reardon, K.M. Tatman, L. Venables, and D.M. Kolodny-Hirsch. 1989. Effect of aerial spraying with Dimilin, Dipel, or Gypchek on two natural enemies of the gypsy moth (Lepidoptera: Lymantriidae). J. Econ. Entomol. 82:1695-1701.

Webb, R.E., J.D. Podgwaite, M. Shapiro, K.M. Tatman, and L.W. Douglass. 1990. Hydraulic spray application of Gypchek as a homeowner control tactic against gypsy moth (Lepidoptera: Lymantriidae). J. Entomol. Sci. 25:383-393.

Webb, R.E., R.L. Ridgway, K.W. Thorpe, K.M. Tatman, A.M. Wieber, and L. Venables. 1991. Development of a specialized gypsy moth (Lepidoptera: Lymantriidae) management program for suburban parks. J. Econ. Entomol. 84:1320-1328.

Webb, R.E., M. Shapiro, J.D. Podgwaite, D.E. Lynn, E.M. Dougherty, R.L. Ridgway, L. Venables, and D.L. Cohen. 1993. Field comparison of different strains of gypsy moth nuclear polyhedrosis virus against gypsy moth (Lepidoptera: Lymantriidae) in Western Maryland in 1990. J. Econ. Entomol. 86:1185-1190. 
Webb, R.E., N.H. Dill, J.D. Podgwaite, M. Shapiro, R.L. Ridgway, J.L. Vaughn, L. Venables, and R.J. Argauer. 1994a. Control of third and fourth instar gypsy moth (Lepidoptera: Lymantriidae) with Gypchek combined with a stilbene disulfonic acid additive on individual shade trees. J. Entomol. Sci. 29:82-91.

Webb, R.E., W.H. McLane, J.A. Finney, L. Venables, G.B. White, A.M. Wieber, and D.L. Cohen. 1994b. Destruction of gypsy moth egg masses (using surfactants, detergents, oils, or conventional insecticides) for quarantine and community action programs. J. Entomol. Sci. 29:305-317.

Webb, R.E., M. Shapiro, J.D. Podgwaite, R.L. Ridgway, L. Venables, G.B. White, R.J. Argauer, D.L. Cohen, J. Witcosky, K.M. Kester, and K.W. Thorpe. 1994c. Effect of optical brighteners on the efficacy of gypsy moth (Lepidoptera: Lymantriidae) nuclear polyhedrosis virus in forest plots with high or low levels of natural virus. J. Econ. Entomol. 87: 134-143.

Webb, R.E., N.H. Dill, J.M. McLaughlin, L.S. Kershaw, J.D. Podgwaite, S.P. Cook, K.W. Thorpe, R.R. Farrar, Jr., R.L. Ridgway, R.W. Fuester, M. Shapiro, R.J. Argauer, L. Venables, and G.B. White. 1996. Blankophor $B B H$ as an enhancer of nuclear polyhedrosis virus in arborist treatments against the gypsy moth (Lepidoptera: Lymantriidae). J. Econ. Entomol. 89:957-962.

Wilkinson, J.D., K.D. Biever, C.M. Ignoffo, W.J. Pons, R.K. Morrison, and R.S. Seay. 1978. Evaluation of diflubenzuron formulations on selected insect parasitoids and predators. J. Ga. Entomol. Soc. 13:227-236.

'Insect Biocontrol Laboratory

Agricultural Research Service

Bldg. 306, Rm. 322

BARC-East

Beltsville, MD 20705

2Delaware State University
Dover, DE 19901

${ }^{3}$ USDA, ARS

Beneficial Insects Introduction Research

Newark, DE 19713
Résumé. On a évalué l'efficacité directe et résiduelle d'insecticides biologiques traditionnels à faibles risques qui sont déjà homologués ou candidats potentiels à l'être pour le contrôle de la spongieuse dans les programmes intégrés de lutte en milieu urbain. L'étude a comparé cinq traitements d'insecticides biologiques (un de Bacillus thuringiensis [Bf] et quatre avec des virus polyèdres nucléiques) et deux autres avec des insecticides à faibles risques (neem et tebufenozide) versus deux insecticides standards à usage fréquent (diflubenzuron et cyfluthrin). Les insecticides standards, diflubenzuron et cyfluthrin, et le tebufenozide ont démontré une excellente activité à tous les stades larvaires autant 1 heure après que 35 jours après. Le $B t$ était définitivement plus efficace lors du second que lors du quatrième stade larvaire; il perdait de son efficacité contre la spongieuse après sept jours. L'efficacité du neem était similaire à celle du $B t$ en ce sens qu'il contrôlait mieux les premiers stades larvaires que les derniers. Même si sa vitesse d'action était plus lente que celle du $B t$, il demeurait très actif contre la spongieuse 21 jours après le traitement. Les virus polyèdres nucléiques, sans l'ajout d'agent Blankophor $\mathrm{BBH}$, produisait des niveaux significatifs de contrôle aux quatre stades larvaires 1 heure après l'application, et ce même si le degré de mortalité était plus élevé chez les premiers stades larvaires que chez les derniers. L'efficacité résiduelle diminuait significativement après une journée. L'addition de Blankophor BBH au mélange de virus dans le réservoir a permis d'améliorer le taux de mortalité 1 heure après l'application et également d'améliorer énormément l'efficacité résiduelle plus de 35 jours après.

Zusammenfassung. Wir bewerteten den direkten und die restliche Wirkung von ausgewählten traditionellen, mit vermindertem Risiko wirkenden und biologischen Insektiziden, die entweder bereits registriert oder aber Kandidaten für eine Registrierung zum Einstaz im Rahmen von integrierten Pflanzenschutzprogrammen zur Bekämpfung von Schwammspinnern in urbanen Räumen sind. Diese Studie vergleicht fünf biologische Insektizide (1 Bacillus thuringiensis $[B t]$ und vier Schwammspimmer-Virus [NPV] Behandlungen) und zwei gegenüber zwei gewöhnlichen eingesetzten Standartinsektiziden (Diflubenzuron und Cyfluthrin). Die Standartinsektizide, Diflubenzuron und Cyfluthrin, und Tebufenozid zeigten eine ausgezeichnete Aktivität gegen alle Larvenstadien, sowohl in der einstündigen Studie als auch in einer 35-stündigen Studie. Btwar deutlich effektiver gegen die zweiten Larvenstadien also gegen die vierten und es verlor nach sieben Tagen deutlich ean Aktivität gegenüber dem Schwammspinner. Die Effektivität des Neemprodukts war ähnlich wie bei $B t$ lag, blieb es noch 21 Tage nach der Anwendung sehr aktiv gegen den Schwammspinner. NPV ohne den Aktivitätbeschleuniger Blankophor BBH war eine wirksame Kontrolle während aller vier Larvenstadien, obwohl die Mortalität für jügere größer war als für ältere Larven. Die Effektivatät der Rückstände war nach einem Tag deutlich Tankmischung führte zu einer verstärkten Abtötung in der einstündigen Studie und einer stark verbesserten Rückstandsaktivität (bis zu 35 Tage). 
Resumen. Evaluamos la eficacia directa y residual de insecticidas tradicionales seleccionados, de riesgo reducido y biológicos, que están registrados o son candidatos para registro para uso en programas de manejo integrado de la mariposa gitana en ambientes urbanos. El estudio comparó 5 tratamientos con insecticidas biológicos (uno con Bacillus thuringiensis [ $B t$ y 4 con virus nuclear poliédrico [VNP]), y 2 insecticidas de riesgo reducido (neem y tebufenozide) contra 2 insecticidas estándar comúnmente usados (diflubenzuron y cyfluthrin). Los insecticidas estándar, cyfluthrin y diflubenzuron, y el tebufenozide, demostraron excelente actividad contra todos los ínstares en estudios residuales de una hora y 35 días. Bt fue claramente más efectivo contra larvas de segundo ínstar que contra larvas de cuarto ínstar, y pierde actividad significativa contra la mariposa gitana después de 7 días. La eficacia del producto neem fue similar a la de Bt en que controló los ínstares jóvenes mejor que a los viejos. A pesar que su velocidad de acción fue más baja que la de $B t$, permaneció altamente activo contra la mariposa gitana 21 días después del tratamiento. VNP, sin realzar su actividad con Blankophor $\mathrm{BBH}$, dio niveles significativos de control para todos los 4 instares larvales en 1 hora, a pesar que la mortalidad fue más alta para los ínstares jóvenes que para los viejos. La efectividad residual fue reducida significativamente después de 1 día. La adición de Blankophor $\mathrm{BBH}$ al tanque de mezcla de VNP mejoró la mortalidad en el estudio de 1 hora y contribuyó ampliamente en la actividad residual (arriba de los 35 días). 